\title{
Residual solvent determination by head space gas chromatography with flame ionization detector in omeprazole API
}

\author{
Saurabh Pandey*1, Preeti Pandey ${ }^{1}$, Raj Kumar ${ }^{2}$, Narendra Pal Singh ${ }^{3}$ \\ ${ }^{1}$ Pranveer Singh Institute of Technology, Kanpur, India, ${ }^{2}$ K.H.B College of Pharmacy, Jaunpur, India, ${ }^{3}$ Institute of Pharmacy, \\ V.B.S Purvanchal University, Jaunpur, India
}

\begin{abstract}
Residual solvents in pharmaceutical samples are monitored using gas chromatography with head space. Based on good manufacturing practices, measuring residual solvents is mandatory for the release testing of all active pharmaceutical ingredients (API). The analysis of residual organic solvents (methanol, acetone, cyclohexane, dichloromethane, toluene) in Omeprazole, an active pharmaceutical ingredient was investigated. Omeprazole is a potent reversible inhibitor of the gastric proton pump $\mathrm{H}+/ \mathrm{K}+$-ATPase. The Head space gas chromatography (HSGC) method described in this investigation utilized a SPB ${ }^{\mathrm{TM}}-624$, Supelco, $30 \mathrm{~m}$ long x $0.25 \mathrm{~mm}$ internal diameter, $1.4 \mu \mathrm{m}$-thick column. Since Omeprazole is a thermally labile compound, the selection of the proper injector temperature is critical to the success of the analysis. The injector temperature was set at $170^{\circ} \mathrm{C}$ to prevent degradation. The initial oven temperature was set

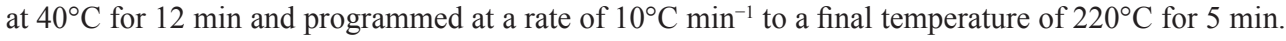
Nitrogen was used as a carrier gas. The sample solvent selected was N,N-dimethylacetamide. The method was validated to be specific, linear, precise, sensitive, rugged and showed excellent recovery.
\end{abstract}

Uniterms: Headspace-gas chromatography. Omeprazole. Method validation. Residual solvents release testing.

Solventes residuais em amostras farmacêuticas são monitoradas utilizando-se cromatografia a gás "headspace". Com base nas boas práticas de fabricação, a medida de solventes residuais é obrigatória para o teste de liberação de todos os ingredientes farmacêuticos (API). Efetuou-se a análise de solventes orgânicos residuais (metanol, acetona, cicloexano, diclorometano, tolueno) em omeprazol, ingrediente farmacêutico ativo. O omeprazol é potente inibidor reversível da bomba de prótons $\mathrm{H}+/ \mathrm{K}+$-ATPase. A cromatografia a gás "headspace" (HSGC) descrita nessa pesquisa utilizou um SPB ${ }^{\mathrm{TM}}-624$, Supelco, de $30 \mathrm{~m}$ de comprimento x $0,25 \mathrm{~mm}$ de diâmetro interno, e coluna de 1,4 $\mu \mathrm{m}$ de espessura. Considerandose que o omeprazol é termicamente lábil, a seleção da temperatura apropriada do injetor é crítica para impedir a degradação. A temperatura inicial do forno foi de $40^{\circ} \mathrm{C}$, por 12 minutos, e programada à taxa de acréscimo de $10^{\circ} \mathrm{C} \mathrm{min}^{-1}$ até a temperatura final de $220^{\circ} \mathrm{C}$, por 5 minutos. Nitrogênio foi utilizado como gás de transporte. Selecionou-se como solvente a $N, N$-dimetilacetamida. O método foi validado mostrando-se específico, linear, preciso, sensível, robusto e com excelente recuperação.

Unitermos: Cromatografia a gás "headspace". Omeprazol. Método de validação. Teste de liberação de solventes residuais.

\section{INTRODUCTION}

Organic solvents are routinely applied during synthesis of drug substances, excipients, or during drug product formulation. They are not desirable in the final product, mainly because of their toxicity, influence on the

*Correspondence: Saurabh pandey, Pranveer Singh Institute of Technology, Kanpur, U.P., India. E-mail: 23.pandey@gmail.com quality of crystals of the drug substance, and their odor or taste, which can be unpleasant for patients. To remove them, various manufacturing processes or techniques (usually under increased temperature or/and decreased pressure) are in use. Even after such processes, some solvents still remain, albeit in small quantities. These small quantities of organic solvents are commonly known as organic volatile impurities (OVIs) or residual solvents (RS). The determination of residual solvents in drug substances, 
excipients or drug products is known to be one of the most difficult and demanding analytical tasks in the pharmaceutical industry. Furthermore, the determination of polar residual solvents in pharmaceutical preparations continues to present an analytical challenge mainly because these compounds are difficult to remove from water or polar solvents (ICH, 2002, 1997; Hymer, 2003). The manufacturing of active pharmaceutical ingredients (API) under GMP (good manufacturing practice) conditions requires adequate control of the quality of the different ingredients involved in the synthesis. Organic residual solvents must therefore be controlled, and their purity determined, before any GMP synthesis.

Inadequate attention has been paid during pharmaceutical investigations. Headspace gas chromatography (HSGC) is a technique where the liquid or solid sample is set in a closed vessel until the volatile components reach equilibrium between the sample and the gas volume above, i.e., the so called "headspace". An aliquot of the headspace is sampled and introduced into a gas chromatographic (GC) column for analysis. Regulatory agencies and pharmacopoeias suggest headspace gas chromatography as the most suitable technique for residual solvent testing for active substances and formulations soluble in water. Residual solvent specification limits, set in accordance with the toxicity of solvents, vary from a few ppm to thousands of ppm. HSGC determination of residual solvents is nowadays a mature technique (Grodowska et al., 2010; Puranik et al., 2009; Groman et al., 2008; Alzaga, 2007; Camarasu, 2006; Michulec et al. 2005; Rocheleau et al., 2004; Klick, 2004; Snow, 2002; Hymer et al., 2003; Iofer et al., 1984).

Direct injection of analytes evaporated through equilibration between liquid (or solid) phase and gas phase into a GC system minimized the contamination of the GC system and the deterioration of the GC column (Kolb et al.,1997). In addition, the automation of equilibrium and injection procedure reduced analysis time and improved reproducibility in the injection procedure.

Omeprazole is a potent reversible inhibitor of the gastric proton pump $\mathrm{H}+/ \mathrm{K}+$-ATPase. The molecular structure of omeprazole is illustrated in Figure 1.

It is composed of a substituted pyridine ring linked

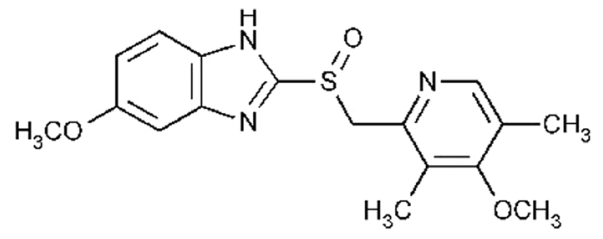

FIGURE 1 - Structural formula of omeprazole. to a benzimidazole by a sulfoxide chain. Chemically designed as 5-methoxy-2-[[(4-methoxy-3,5-dimethyl-2pyridinyl)methyl]sulfinyl]-1 $H$-benzimidazole. Omeprazole is a white powder, slightly soluble in water, but is highly soluble in alkaline solutions as the negatively charged ion. It is an ampholyte with $\mathrm{pKa}=4$ (pirydinium ion) and 8.8 (benzimidazole). In solution, Omeprazole degrades rapidly at low $\mathrm{pH}$ values, and it is photo and heat sensitive (Sarisuta et al., 1997). Its molecular formula and weight is $\mathrm{C}_{17} \mathrm{H}_{19} \mathrm{~N}_{3} \mathrm{O}_{3} \mathrm{~S}$, and 345.4, respectively (Marzocchi et al., 2001). Omeprazole is known for its high potential to interact with other drugs (United States Pharmacopoeia, 2006; Anderson, 1996; Mayer,1996). The aim of this study was to develop a HSGC method for analysis of residual solvents in omeprazole API. The residual solvents were compared to standard solvents and the ICH standard residual solvents limit.

\section{EXPERIMENTAL}

\section{Material}

Used Chemicals were obtained from the following suppliers: methanol (sigma-aldrich, Mumbai, India), acetone, cyclohexane, dichloromethane (DCM) and toluene (Qualigens, Mumbai, India) N,N-dimethylacetamide (DMA) HPLC grade (Spectrochem, Mumbai, India). Omeprazole API was obtained from Shipra Pharma, Mumbai, India.

\section{Instrumentation}

A Gas chromatograph (Agilent technologies 6890N) equipped with a flame ionization detector, a Headspace sampler (Agilent technologies G1888) was used to load the sample. An analytical balance (XS 205 from Mettler Toledo) and autopippette (100 - $1000 \mu \mathrm{L}$ from Eppendorf) were used. The headspace injector and GC conditions are provided in Table I.

\section{Chromatographic conditions}

A volume of $1 \mathrm{ml}$ standard and sample solution was injected into the $\mathrm{GC}$ injection port. The temperature of the injection port was maintained at $170{ }^{\circ} \mathrm{C}$ at a split ratio of $1: 10$, with nitrogen as a carrier gas. The pressure was maintained at 14 psi with flow of $1 \mathrm{~mL} \mathrm{~min}^{-1}$. The temperature of the detector was set at $250^{\circ} \mathrm{C}$. Temperature gradient was maintained at $40{ }^{\circ} \mathrm{C}$ for twelve min and then increased at a rate of $10^{\circ} \mathrm{C} \mathrm{min}^{-1}$ up to $220^{\circ} \mathrm{C}$ to a final temperature of $220^{\circ} \mathrm{C}$ and maintained for $5 \mathrm{~min}$. 


\section{Preparation of standard and sample vial}

DMA was selected as the standard and sample diluent because of its ability to dissolve a wide variety of substances. It has a high boiling point that does not interfere with more volatile solvents, analyzed by GC. A common standard stock solution in DMA containing all the known residual solvents of Omeprazole API (i.e., methanol, acetone, cyclohexane, dichloromethane and toluene) was prepared in such a way that it had a final concentration of $3000 \mathrm{ppm}$ for methanol, $5000 \mathrm{ppm}$ for acetone, $100 \mathrm{ppm}$ for dichloromethane, $890 \mathrm{ppm}$ for toluene and $3880 \mathrm{ppm}$ for cyclohexane.

The standard vial was prepared with $1 \mathrm{~mL}$ of the standard solution and the sample vials were prepared with approximately $120 \mathrm{mg}$ of sample with $1 \mathrm{~mL}$ DMA as diluent.

\section{Method validation}

The method validation was done by evaluating specificity, limit of detection (LOD) and limit of quantitation (LOQ), linearity, accuracy, repeatability, ruggedness, system suitability and method precision of residual solvents as indicated in the ICH harmonised tripartite guideline (1997, 2002).

\section{RESULT AND DISCUSSION}

\section{Specificity}

The omeprazole API sample was spiked with dichloromethane, toluene, methanol, cyclohexane and acetone individually, and each sample was chromatographed to examine interference, if any, of the residual solvent peaks with each other. The retention time for standard methanol, acetone, dichloromethane, cyclohexane and toluene was found to be $3.41,5.23,6.24,12.14$ and $18.26 \mathrm{~min}$, respectively. A typical chromatogram of standard solution is shown in Figure 2.

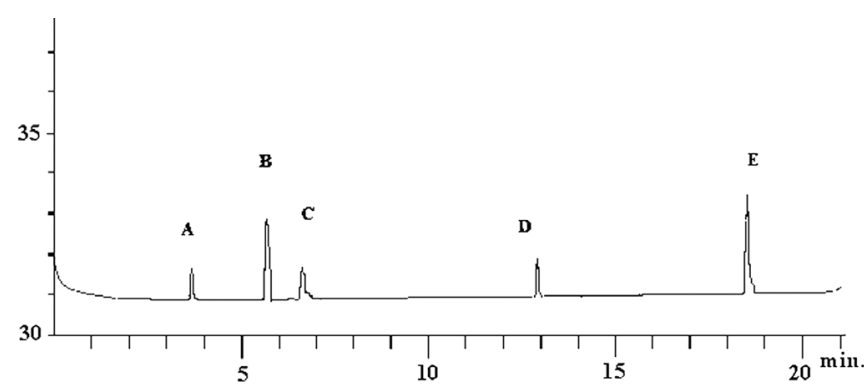

FIGURE 2 - Typical chromatogram showing retention time for different residual solvents. A-methanol, B-acetone, C-DCM, D-cyclohexane, E-toluene.

\section{Linearity}

The linearity of the method was determined by making injections of each residual solvent over the range $15-150 \%$ LOQ. Three replicates were performed at each level. The calibration curves were obtained with the average of peak area ratios of three replicates. The correlation coefficient $\left(\mathrm{r}^{2}\right)$ values for all residual solvents were found to be higher than 0.997 and the calibration curves were linear within the range. Table II shows the linearity values for the residual solvents.

TABLE I - Headspace injector and GC conditions

\begin{tabular}{lcll}
\hline Headspace injector & \multicolumn{2}{c}{ Gas Chromatography } \\
\hline Oven equilibration temperature & $80^{\circ} \mathrm{C}$ & Column & $\begin{array}{l}\mathrm{SPB}^{\mathrm{TM}}-624, \text { Supelco, 30 m length, } \\
0.25 \mathrm{~mm} \text { internal diameter, and } 1.4 \mu \mathrm{m}\end{array}$ \\
& & & $\begin{array}{l}\text { film thickness } \\
\text { Nitrogen }\end{array}$ \\
Loop temperature & $90^{\circ} \mathrm{C}$ & Carrier gas & $1.0 \mathrm{~mL}$ per minute (Linear velocity \\
Transfer line temperature & $100^{\circ} \mathrm{C}$ & Flow rate & $26 \mathrm{~cm} / \mathrm{sec}$ ) \\
& & & $170{ }^{\circ} \mathrm{C}$ \\
GC cycle time & $45 \mathrm{~min}$ & Injector temperature & $250^{\circ} \mathrm{C}$ \\
Oven/vial, equilibration time & $30 \mathrm{~min}$ & Detector temperature & $1: 10$ \\
Pressurization time & $0.5 \mathrm{~min}$ & Split ratio & Initial $40{ }^{\circ} \mathrm{C}$, held for 12 minutes \\
Loop fill time & $1.0 \mathrm{~min}$ & Oven temperature program & Increase $@ 10^{\circ} \mathrm{C}$ per minute to $220^{\circ} \mathrm{C}$ \\
Injection time & $0.5 \mathrm{~min}$ & & Held at $220^{\circ} \mathrm{C}$ for 5 minutes \\
Loop equilibration time & $0.5 \mathrm{~min}$ & & \\
Vial pressure & $14 \mathrm{psi}$ & &
\end{tabular}




\section{Limit of Detection (LOD) and Quantitation (LOQ)}

The LOD and LOQ were calculated by instrumental and statistical methods. For the instrumental method, LOD is determined as the lowest amount to detect, and LOQ is the lowest amount to quantify, by the detector. The LODs of residual solvents in Omeprazole API were determined based on a signal-to-noise ratio of 3:1. The LOQs of residual solvents were determined based on a signal-to-noise of ratio 10:1. The values for the LOD and LOQ for dichloromethane, toluene, methanol, cyclohexane and acetone are shown in Table II.

\section{Accuracy (recovery)}

A known amount of sample (120 mg) was taken separately in five different vials and spiked with known quantities of DCM, toluene, methanol, cyclohexane and acetone at three different levels $(50,100 \& 150 \%$ of Quantization Limit) in triplicate. The results are presented in Table III. From accuracy data, the \% recovery of residual solvents was found within the limits (80-120\%) and \% RSD for area did not exceed 10.0 for each solvent as per the ICH guideline. Results indicate that the method has an acceptable level of accuracy.

\section{Precision}

For the system precision, a single injection of blank and six replicate injections of standard solution were observed. Intermediate precision study was carried out by a different analyst, on a different instrument and on another day. Table IV shows the results for intermediate precision. The \% RSD for each solvent was found to be less than 10 and system suitability was passed.

\section{Robustness}

To demonstrate the robustness of the method, the system suitability criteria with slight variations in method parameters, was verified. The following parameters were changed: column oven temperature $\pm 5^{\circ} \mathrm{C}$ from the ideal conditions (initial column oven temperature at $35^{\circ} \mathrm{C}$ and $45^{\circ} \mathrm{C}$ ), the flow rate $\pm 10 \%$ from the ideal conditions (flow rate $0.9 \mathrm{~mL} / \mathrm{min}$ and $1.1 \mathrm{~mL} / \mathrm{min}$ ), the split ratio $\pm 10 \%$ from the ideal conditions (the split ratio of 1:9 and 1:11), two columns of different serial numbers. The results are shown in Table V. For the robustness study, individual $\%$ RSD should not exceed 10.0 and cumulative (overall) $\%$ RSD should not exceed 15.0, for each component, and system suitability should pass.

\section{System suitability}

The system suitability criterion was taken to be the resolution between the critical pairs, i.e., acetone and dichloromethane. The system suitability was evaluated by injecting the standard solution on various days before star-

TABLE II - Validation results for residual solvents

\begin{tabular}{|c|c|c|c|c|c|c|}
\hline \multirow[t]{2}{*}{ Solvent } & \multirow{2}{*}{$\frac{\text { Specificity }}{\text { RT (min.) }}$} & \multicolumn{3}{|c|}{ Linearity } & \multirow{2}{*}{$\begin{array}{c}\text { Limit of } \\
\text { Detection (LOD) } \\
(\mathrm{ppm})\end{array}$} & \multirow{2}{*}{$\begin{array}{c}\text { Limit of } \\
\text { Quantitation (LOQ) } \\
(\mathrm{ppm})\end{array}$} \\
\hline & & Slope & Intercept & $\begin{array}{c}\text { Correlation } \\
\text { coefficient }\left(\mathrm{r}^{2}\right)\end{array}$ & & \\
\hline$\overline{\mathrm{MeOH}}$ & 3.41 & 0.08 & 5.33 & 0.998 & 1.03 & 2.89 \\
\hline Acetone & 5.23 & 0.27 & 1.98 & 0.999 & 2.18 & 4.25 \\
\hline DCM & 6.24 & 0.06 & 0.20 & 0.998 & 0.96 & 2.58 \\
\hline Cyclohexane & 12.14 & 1.07 & 9.30 & 0.999 & 1.19 & 3.16 \\
\hline Toluene & 18.26 & 0.20 & 2.58 & 0.997 & 1.03 & 2.82 \\
\hline
\end{tabular}

TABLE III - Accuracy data for different residual solvents

\begin{tabular}{cccccc}
\hline $\begin{array}{c}\text { Spiking level } \\
\text { (\% of QL) }\end{array}$ & $\begin{array}{c}\text { MeOH } \\
\text { (\% recovery) }\end{array}$ & $\begin{array}{c}\text { Acetone } \\
\text { (\% recovery) }\end{array}$ & $\begin{array}{c}\text { DCM } \\
\text { (\% recovery) }\end{array}$ & $\begin{array}{c}\text { Cyclohexane } \\
\text { (\% recovery) }\end{array}$ & $\begin{array}{c}\text { Toluene } \\
\text { (\% recovery) }\end{array}$ \\
\hline $50 \%$ & 106.12 & 101.12 & 111.12 & 100.12 & 96.12 \\
$100 \%$ & 97.02 & 94.2 & 100.2 & 99.4 & 97.4 \\
$150 \%$ & 100.94 & 100.94 & 108.94 & 98.94 & 98.14 \\
\% Average & $101.94 \pm 4.56$ & $98.75 \pm 3.94$ & $106.75 \pm 5.77$ & $99.49 \pm 0.6$ & $97.22 \pm 1$ \\
$\begin{array}{c}\text { Recovery } \\
\text { \% RSD }\end{array}$ & 4.47 & 3.99 & 5.40 & 0.6 & 1.03 \\
\hline
\end{tabular}


TABLE IV - Intermediate precision data

\begin{tabular}{lccccc}
\hline & \multicolumn{5}{c}{ Intermediate Precision } \\
\hline Mean (ppm) & MeOH & Acetone & DCM & Cyclohexane & Toluene \\
SD & 144.60 & 972.5 & 5.87 & 2970 & 125 \\
\%RSD & 12.05 & 18.60 & 0.14 & 30.24 & 9.76 \\
\hline
\end{tabular}

TABLE V - System suitability under robustness condition

\begin{tabular}{lccccc}
\hline Conditions & \multicolumn{4}{c}{$\%$ RSD for standard solution under different robustness conditions } \\
\cline { 2 - 5 } & $\mathrm{MeOH}$ & Acetone & DCM & Cyclohexane & Toluene \\
\hline Control & 5.74 & 1.42 & 2.41 & 0.79 & 5.89 \\
Oven temp. decrease & 3.85 & 1.89 & 2.32 & 1.62 & 4.18 \\
Oven temp. increase & 7.65 & 3.48 & 5.07 & 2.58 & 8.59 \\
Flow decrease & 2.95 & 1.62 & 2.44 & 2.04 & 4.07 \\
Flow increase & 5.32 & 4.27 & 2.56 & 2.88 & 4.91 \\
Split Ratio decrease & 4.30 & 2.78 & 3.33 & 3.30 & 5.40 \\
Split Ratio increase & 2.18 & 1.51 & 2.63 & 1.18 & 2.30 \\
Column change & 7.92 & 3.88 & 5.17 & 6.21 & 9.06 \\
\hline
\end{tabular}

TABLE VI - System suitability

\begin{tabular}{lc}
\hline Experiment & $\begin{array}{c}\text { Resolution between acetone } \\
\text { and dichloromethane }\end{array}$ \\
\hline Specificity & 1.943 \\
Precision & 1.939 \\
Accuracy & 1.941 \\
Linearity & 1.911 \\
LOD/LOQ & 1.949 \\
\hline
\end{tabular}

ting any exercise during the validation study. The criterion for system suitability was that the resolution between the above-mentioned critical pair should not be less than 1.5 and it was found to be well above the minimum passing limit (Table VI).

\section{CONCLUSION}

A single, rapid and highly selective HSGC method was developed and validated for the quantification of residual solvents present in Omeprazole API through an understanding of the synthetic process, nature of solvents and nature of stationary phases of columns. The residual solvents methanol, acetone, cyclohexane, dichloromethane and toluene were determined. The developed method is specific, accurate, precise and rugged as per ICH guidelines.

\section{REFERENCES}

ALZAGA, R.; RYAN, R.W.; TAYLOR-WORTH, K.; LIPCZYNSKI, A.M.; SANDRA, P.J. A generic approach for the determination of residues of alkylating agents in active pharmaceutical ingredients by in situ derivatizationheadspace-gas chromatography-mass spectrometry. $J$. Pharm. Biomed. Anal., v.45, n.3, p.472-479, 2007.

ANDERSSON, T. Pharmacokinetics, metabolism \& interactions of acid pump inhibitors: focus on omeprazole, lansoprazole, pantoprazole, Clin. Pharmacokinet., v.31, n.1, p.9-28, 1996.

CAMARASU, C.; MADICHIE, C.; WILLIAMS, R. Recent progress in the determination of volatile impurities, Trends Anal. Chem, v.25, n.8, p.768-777, 2006.

GRODOWSKA, K.; PARCZEWSKI, A. Analytical methods for residual solvents determination in pharmaceutical products. Acta Pol. Pharm. Drug Res., v.67, n.1, p.13-26, 2010.

GROMAN, A.; KAMIE, A. Validation of an analytical procedure ñ control of residual solvents in pharmaceutical substance. Acta Pol. Pharm. Drug Res., v.65, n.6, p.783-787, 2008.

HYMER, C.B. Residual solvent testing: a review of gaschromatographic and alternative techniques. Pharm. Res., v.20, n.3, p.337-344, 2003. 
INTERNATIONAL CONFERENCE OF HARMONIZATION. Impurities: Guideline for residual solvents. ICH harmonised tripartite guideline, 1997. Available at: <http://www.ich. org>. Accessed on: 09 jan. 2008.

\section{INTERNATIONAL CONFERENCE ON HARMONIZATION.} Impurities: Guideline for Residual Solvents (Maintenance), 2002. Available at: <http://www.ich,org > Accessed on: 09 jan. 2008.

IOFEE, B.V.; VITENBERG, A.G. Head-Space analysis and related methods in gas chromatography. New York: John Wiley \& Sons, 1984. p.23-24.

KLICK, S.; SKOLD, A. Validation of a generic analytical procedure for determination of residual solvents in drug substances. J. Pharm. Biomed. Anal., v.36, n.2, p.401-409, 2004.

KOLB, B.; ETTRE, L. S. Static headspace-gas chromatography: theory and practice. New York: Wiley-VCH, 1997. p.3-4.

MARZOCCHI, L.; MOYANO, J.R.; ROSSI, A.; MUNOZ, P.; ARIAS, M.J.; GIORDANO, F. Current status of ATP-ase proton pump inhibitor complexation with cyclodextrins. Biog. J. Armenia, v.53, special issue, p.176-193, 2001.

MAYER, U.A. Interactions of proton pump inhibitiors with cytochromes p450, consequences for drug interactions. Yale J. Biol. Med, v.69, n.3, p.203-209, 1996.
MICHULEC, M.; WARDENCKI, W. Development of headspace solid-phase microextraction-gas chromatography method for the determination of solvent residues in edible oils and pharmaceuticals. J. Chromatogr. A, v.1071, n.1-2, p.119$124,2005$.

PURANIK, S.B.; PAWAR, V.; LALITHA, N.; PAI, P.N.S.; RAO, G.K. Residual solvent analysis in hydrochloride salts of active pharmaceutical ingredients. Pak. J. Pharm. Sci., v.22, n.4, p.410-414, 2009.

ROCHELEAU, M.J.; TITLEY, M.; BOLDUC, J. Measuring residual solvents in pharmaceutical samples using fast gas chromatography techniques $J$. Chromatogr. B, v.805, n.1, p.77-86, 2004.

SARISUTA, N.; TOURTIP, T.; CHUARCHAROERN, S. Chemical stability and mechanism of degradation of omeprazole. Thai. J. Pharm. Sci., v.22, n.2, p.81-88,1998.

SNOW N.H.; SLACK G.C. Head-space analysis in modern gas chromatography. Trends Anal. Chem , v.21, n.9-10, p.608617, 2002.

UNITED STATES PHARMACOPOEIA. Rockville: United States Pharmacopoeia Convention, 2006. p.1577-1578.

Received for publication on $16^{\text {th }}$ July 2010 Accepted for publication on $28^{\text {th }}$ February 2011 